\title{
Public Relations: Too Little Emphasis on Communication
}

Review paper _ UDK 001.11:316.77 _ Received on 19 April 2016

\section{Betteke van Ruler}

Professor Emerita in Communication Science, University of Amsterdam, Amsterdam School of Communications Research ASCoR, The Netherlands. Email: ruler@telfort.nl

\section{Abstract}

Examining the literature on public relations, the notion emerges that all major public relations approaches recognize communication as a means to "do" public relations; some even use "communication" in the name of their approach. However, as a key concept that needs to be defined and discussed, communication is largely overlooked. After close reading of relevant literature in order to understand what is really understood under "communication", there is hardly any reference to be found to (recent) communication theories. Is it because most public relations scholars seem to hold a non-communication view of communication?

Keywords: public relations theory, communication theory, communication science 


\section{Introduction}

Over a decade ago, during the 2003 ICA conference, one of the panel sessions was on the issue of "what should be the key concept of public relations". This was because many leading scholars in the field were in favor of the concept of relationship as a key concept in public relations and were changing their focus into research on relationships; it was made explicit by John A. Ledingham and Stephen D. Bruning (2000, p. xi), who in their widely discussed reader stated that the concept of relationship should replace the concept of communication "since professionals seem to perceive that the production and dissemination of communication messages (emphasis added, BvR) is the answer to every public relations problem". I do not think we have had such a discussion anymore ever since, but volumes of public relations journals and mainstream text - and handbooks clearly show that many scholars have indeed incorporated relationships as key concept; it is also obvious that most of them do not tend to see communication theory as important for studying public relations.

\subsection{Why is communication important?}

In this paper, I want to delineate the concept of communication. First, because I am a communication scientist and I study public relations from a communication scientific perspective. Secondly, because what one researcher would call "relationships" could very well be what another would call "communication". It is, therefore, important to define what the concept of communication could mean and what communication theory could add to public relations. Thirdly, because practitioners as well as professional associations have altered their professional names into something incorporating "communication" ("corporate communication", “communication management”, or just “communication”), and universities followed suit, developing programs in "corporate communication" or "communication management". Most important, however, is my fourth reason and that is that - although there is a lot of communication we should not define as public relations - most scholars agree that good public relations depends largely on behavior of (people in) organizations (cf. Birkigt, Stadler, 1986). Although not everybody would agree that behavior is communication, all behavior is communicative. So, public relations is impossible without a view on how communication works. Yet, as I will show in the third section of this paper, well-founded 
theoretical notions on communication are largely overlooked in most public relations approaches. It could very well be that the reason for denying the role of communication as a key concept is a lack of understanding of what communication is and how it works.

\section{Communication unraveled ${ }^{1}$}

\subsection{The concept of meaning}

To unravel communication, we need to find some core concepts that are helpful in the discussion of the container term "communication" with regard to public relations. Karl Erik Rosengren (2000) suggests that, above all, communication can be said to be about the process of the creation of meaning. Meaning involves questions such as: How do people create meaning psychologically, socially, and culturally?; How are messages understood? and How does ambiguity arise and how is it resolved?. "Communication does not happen without meaning, and people create and use meaning in interpreting events.” (Littlejohn, 1992, p. 378)

Meaning can be explained as the "whole way in which we understand, explain, feel about, and react towards a given phenomenon" (Rosengren, 2000, p. 59). At first sight, the use of the concept of meaning would focus on so-called interpretive theories, but this is not necessarily the case; it depends on what is meant by "meaning" (Preyer et al., 2003). According to Susanne Langer (1967), meaning has two dimensions: a denotative and a connotative one. The denotative meaning of a phenomenon is the meaning one can find in a dictionary. It is overt, being the inter-subjectively shared signification of a word. The connotative meaning refers to all personal feelings and subjective associations of a symbol. A dog is denotatively a four-legged domestic animal. But for some, the word $\operatorname{dog}$ has connotations of fear while for others it contains connotations of tenderness. Many communication scientists stress that the connotative meaning is what drives cognition and behavior (in sending as well as in receiving) (see, e.g., Berlo, 1960; Littlejohn, 1983, 1992; Rosengren, 2000; Thayer, 1987).

1 A deeper understanding of the concept of communication can be found in Ruler, B. van (2004). The communication grid: An introduction of a model of four communication strategies. Public Relations Review, 30, 123-143. 


\subsection{The direction of communication}

Regarding the direction of the communication, James E. Grunig's models of public relations represent a first classification of insights into this aspect. He distinguished PR models that stress a one-way model of communication and models that emphasize a two-way model. Shannon's model (Shannon, Weaver, 1949) is a widely used one-way model of communication in which the transmission of signals through a (telephone) channel is described. By contrast, an example of a two-way model of communication can be found in Wiener's cybernetics theory (1948), which showed how communication processes can be seen in terms of action and reaction. Recently, many researchers describe communication as a fully interactive process in which all people have equal access to the communication process and the possibility to take initiative; this goes further than just action and reaction.

\subsection{Emission or effect}

In the search for a more precise way of distinguishing between emission and effect, the Belgian communication scientist Guido Fauconnier (1990) is helpful. He claimed that, in practice, many are concerned solely with expression. He promoted instead a scientific concept of communication in which one is not only concerned with the way in which a message is expressed, but also how this affects the addressee (Fauconnier, 1990, p. 74). Communication which is limited to expression is, of course, a kind of one-way model, but without any concern for the destination of what is expressed. The only concern is in relation to the expression itself, or "the emission". This seems similar to what Grunig (1989) calls an asymmetrical one-way model of public relations, since he describes this as a practical, unscientific, view of communication which implies that there is no need to do any kind of research, nor to segment target groups in a methodical way, or to know anything about potential receivers, let alone about different publics. I would rather call it an "un-addressed process". This suggests that communication had better be described by Grunig as an "emission" rather than as a one-way process, because there is no consideration whatsoever for the destination of what is expressed. As soon as one starts to take account of the destination, for example in terms of the "intended reach of the message transmitted", then attention is focused on some kind of preliminary effect. Questions arise such as "Did the predefined target group notice 
my message?" and "Did I reach any of the predefined target groups?". Communication as emission is fully sender-oriented, in so far that effects play no role at all, not even at the clipping level. In this view, communication is seen "as a magic bullet", as Wilbur Schramm (1971) cynically described. In most theories, the concept of effect is described in a different way than as just reaching someone.

\subsection{The concept of effect}

In the 1960s, Raymond A. Bauer (1964) concluded that there are two different views regarding the idea of effects. The first of these, which he describes as the social model, "held by the general public and by social scientists when they talk about advertising, and somebody else's propaganda, is one of the exploitation of man by man. It is a model of one-way influence: The communication does something to the audience, while to the communicator is generally attributed considerable latitude and power to do what he pleases to the audience." (Bauer, 1964, p. 319). These kinds of communication models are normally called "linear effect models" (Littlejohn, Foss, 2011) or sometimes also "limited effect models" (Stappers et al., 1990). The claim is that the sender tries to persuade the audience to accept the meaning of the sender as its own meaning. Bauer (1964, p. 319) called his second model "the scientific model of communication as a transactional process in which two parties each expect to give and take from the exchange approximately equitable values". Although this scientific model allows for influence, it does not follow a linear causal model. Bauer stated that, while research shows that the scientific model is by far the more adequate of the two, it is the social model that is dominant in practice.

Bauer's social model of one-way influence is equivalent to Grunig's two-way asymmetrical model, while the two-way symmetrical model reflects Bauer's scientific model. Bauer, however, talks about one-way influence in his social model because of the presumed linear causality. I would suggest that it is indeed questionable whether we can use "two-way" to describe the social model, as the addressee is seen as an object able only to receive or, possibly, answer the speaker's questions. The addressee is not a full participant in the two-way process, which is why I prefer to describe Grunig's two-way asymmetrical model as "controlled one-way" communication; it enables us to differentiate between communication as emission, as a 
controlled one-way process, and as a two-way process in which all participants have equal possibility to take the initiative.

\subsection{The concept of influence}

There is yet another concept that needs to be discussed: the concept of influence. Early communication theories focused on communication as a one-way process in which a sender acts on an addressee, but what this "act on" was remained a matter of debate. Some theories view communication most of all as a transmission process, a flow of information in which a sender disseminates a message by revealing its meaning through symbols. The focus is then on the flow of information, as Shannon did (Shannon, Weaver, 1949), and this information is seen as "objective", thereby implicitly focusing on the denotative side of meaning. A typical definition within this scope of communication is: "Communication is the transmission of information, ideas, attitudes, or emotion from one person or group to another (or others)" (for an overview of these views on communication, see Littlejohn, Foss, 2011). Brenda Dervin (1991) would call this a non-communication approach to communication and most communication scholars would call it outdated.

Other theories view communication as an attempt by a sender to produce a predefined attitudinal change in the addressee - that is, a change in the (connotative) meaning of the situation as perceived by the latter. A well-known theory of this type is the Two-Step Flow theory, which predicts that mass media inform certain people, who on their part act as opinion leaders, influencing the meanings perceived by others. The focus here is on the flow of influence (Lin, 1971). It is obvious that there is no flow of influence without a flow of information, but a flow of information is not necessarily also a flow of influence, at least not in such a way that the sender can predict how it will be interpreted by the addressee (Nillesen, 1998). However, as long as information is seen as objective, there is no need to differentiate between information and influence. The former view of one-way communication can be called a transmission model; the latter a persuasion model. The one-way transmission view is concerned with the transfer of a message in order to influence the addressee without emphasis on altering feelings and emotions, while the one-way persuasion view is about changing the addressee's behavior. The transmission model focuses on the transmission of 
(denotative) meaning, while the persuasion model emphasizes the one-way synchronization of (connotative) meaning, held by the audience.

\subsection{Consensus or diachrony}

Most recent communication scientific approaches to communication view it as a fundamental two-way process which is interactive and participatory at all levels. In communication science, this cultural shift brought a paradigm shift from a sender-receiver orientation to an actor orientation (Bentele, Rühl, 1993; Putnam, Pacanowsky, 1983; Thayer, 1987). In other words, a process in which all actors can be active and take initiatives. That is why the emphasis nowadays is on communication as a process in which meanings are created and exchanged by the parties involved. Once again, there are two different views on this fundamentally two-way process. For some scientists, this process actually creates a shared meaning - a new denotative or overt meaning, i.e. "consensus” (Schramm, 1965; Susskind et al., 1999; Littlejohn, Foss, 2011). This equates the two-way symmetrical model of Grunig.

For others, the key to communication is the fact that it creates meanings inter-subjectively (see, for example, Putnam, Pacanowski, 1983) and in an ongoing process (Weick, 1995). The key word in this approach is dialogue, in its ancient Greek definition of "a free flow of words and its interpretations". This fits the diachronic view of communication, as Thayer $(1968,1987)$ holds, stipulating that communication is an ongoing process of learning in which meanings develop. Thayer opposed this to what he called a "synchronization of the meaning of the audience with the meaning of the sender".

The idea of an ongoing process of learning in which meanings develop is very well illustrated by the helical model of Frank E. X. Dance (1970), in which he shows that meanings develop over time. He uses a helix "for the coming curve of the helix is fundamentally affected by the curve from which it emerges". (...) "The communication process, like the helix, is constantly moving forward and yet is always to some degree dependent upon the past, which informs the present and the future.” (Dance, 1970, p. 101) 


\subsection{Five approaches to communication}

Overlooking communication theory, we may conclude that we can find at least five different approaches to communication, of which the first one is seen as purely pre-scientific and the second as a purely technical, non-communication approach.

1. One way uncontrolled: mere expression of ideas/messages,

2. One way controlled: transmission of messages to target groups,

3. Two way asymmetry: persuasion of audiences in a predefined way,

4. Two way symmetry: consensus-building with publics,

5. Evolutionary: diachronic creation of meanings of involved actors.

\section{Major concepts of public relations}

Looking at common practice in public relations, cynics would probably say that public relations is most of all gaining the attention of journalists for products, services, policies, and ideas of their clients, by using tricks and spin (f.e. Davis, 2002; l'Etang, 2004; Heath, 2013). There is no doubt that this kind of service is (a form of) communication, and this is certainly part of public relations practice. However, public relations scholars have different ideas about what public relations is. I will review some basic schools of thought which I think cover the academic field of thinking about public relations over time, at least in mainstream approaches, and I will shortly analyze the view on the concept of communication in these schools of thought.

\subsection{The reputation approach}

A widespread approach to public relations is corporate communication (Argenti, 1994; Dolphin, 1999; Riel, 1995, 2001; Cornelissen, 2014), also often referred to as "reputation management" (numerous books and websites). Charles J. Fombrun and Cees B. M. van Riel (2004) are the most prolific authors in this area, claiming that a good corporate image (reputation) is critically important for managers to survive. In doing so, they all build implicitly - on the public relations books of founding father Edward Bernays $(1923,1955)$ 
who claimed that public relations is basically a means of "engineering of consent". This is what Grunig criticized as a two-way asymmetrical model of public relations.

The way to manage corporate image (reputation) is to define a desired corporate image and a desired organizational identity and develop "corporate communication”, which van Riel (2001, p. 5; 2007, p. 5) defines as "the orchestration of all instruments of organizational identity (communications, symbols, behaviors) in such a way that a positive reputation is created or maintained by groups with which the organization has a dependency relationship". In previous work (e.g. van Riel, 1995), van Riel focused on influencing the image by well-planned communication campaigns. Van Riel does not describe what he means by communication and gives no definition at all, but it must be a basic concept since it is even used in the title of his conceptual framework. Still, he does not use communication theory much, but relies on psychological and organizational theories.

His definition of corporate communication shows that he has in mind a persuasion model of communication, in which the emphasis is on the synchronization of (connotative) meaning in target groups, in other words, what David K. Berlo (1960) called a social model of communication. The idea of image building stems from Klaus Birkigt and Marinus M. Stadler (1986), who see a causal effect of the self-presentation of an organization and its image. Non-critically cited by van Riel, with communication they mean "the sending of verbal or visual messages” (Birkigt, Stadler, in van Riel, 1995, p. 32), and this is seen as the most flexible corporate identity instrument to influence the corporate self-presentation: "The flexibility of communication lies in the fact that more abstract signals can be transmitted directly to target groups. A company can, for instance, inform its target group directly that it is innovative. If the same message were to be conveyed only by the behavior of the company, the process would be much longer and more laborious" (p. 32). All in all, most reputation approaches hold a one-way persuasion model of communication.

\subsection{The relationship approach}

The state-of-the-art Encyclopedia of Public Relations (Heath, 2013), the widely discussed Ledingham-and-Bruning reader (2000), Scott M. Cutlip; Alen H. Center and Glen M. Broom's widely used handbook (see Broom, Sha, 2013), Grunig, Grunig and David M. Dozier’s final 
overview (2002) as well as recent volumes of public relations journals and textbooks - all these show that many in the academic public relations community now consider public relations as a management function concerned with building relationships with publics (stakeholders) in order to preserve or reduce conflicts and build trust, by using a definition of public relations such as "the management function that establishes and maintains mutually beneficial relationships between an organization and the publics on whom its success or failure depends".

Since Ledingham and Bruning (2000) argue that organizational and interpersonal communication theory are needed to build a relational approach to public relations, it is obvious that they do not deny that there is communication in public relations and that communication theory is important. It is therefore surprising that they argued that communication should no longer be a vital concept of public relations. But "means are confused with ends" they claim (Ledingham, Bruning, 2000, p. xi). For them, relationships are the end of public relations, while communication seems to be only a technical means and would probably best be seen as a (reasonably simple) building block in producing beneficial relationships if used properly. "Recently", they say (Ledingham, Bruning, 2000, p. xii), "the role of the 'journalist in residence' - offering advice on ways to get an organization's name in the press - has been supplanted to some degree by that of the 'expert prescriber' - a public relations counselor who advises client companies on matters of public policy. Nonetheless, many organizations still view public relations primarily as a means of generating favorable publicity. Their rationale for public relations is found not in the management of reciprocal relationships between an organization and its publics, but rather in 'the credibility' attached to information that has been examined by reporters (through) third party endorsement by the media", they note (Ledingham, Bruning, 2000, p. xii).

Obviously, Ledingham and Bruning argue against what Grunig and Hunt (1984) called a publicity model of public relations; and they appear to equate that with communication in public relations. That would mean that they view communication as just an emission; if that is the case, their ideas about communication are pre-scientific.

Broom et al. (2000) repeat Ehling in the classic treatise Excellence in Public Relations and Communication Management, edited by Grunig (1992). William P. Ehling (1992, p. 633) stated in that book that "the primary end state of public relations is the maximization through 
communication of the difference between cooperation and conflict such that cooperation becomes the prime benefit". But Broom et al. argue that it is relationships between organizations and stakeholders that must be central to a theory of public relations and organizational effectiveness, presenting a model to measure relationships. They, too, seem to view communication only as a means that managers can choose to use with a pre-fixed beginning and a pre-defined, not to be discussed, effect, following a transmission view on communication.

\subsection{The symmetry approach}

Grunig $(1989,1992)$ developed the two-way symmetrical model of public relations for excellent public relations to contrast it with asymmetrical public relations as Bernays propagated. The two-way symmetrical model is without any doubt the most widespread approach to public relations in the academic community all over the world. In an overview of his work, Grunig (2001, p. 28) writes, "symmetry means that communicators keep their eyes on a broader professional perspective of balancing private and public interests. Their job consists of more than argumentation of 'a wrangle in the marketplace'." They must listen as well as argue. But this does not mean that they do not argue or attempt to persuade. This is why Grunig (2001; see also Grunig et al., 2002; Grunig, 2009) in his more recent work suggests that excellent public relations can be asymmetrical in its practice as well, as long as it is symmetrical in its overall intentions. He calls this a mixed motive model of public relations in which balancing of interests between organization and stakeholders is the basic philosophy.

Since "symmetry" was a term that was widely criticized, he suggested that the best term for symmetrical public relations is "dialogical public relations" (Grunig, 2001). Grunig wrote that he borrowed the term "dialogical" from relationships literature and makes no reference to any communication theory, although in communication theory, too, this is a basic concept. Habermas even sees dialogue as the only form of social interaction that can be called "communication" (Hetebrij, 2011), and it is certainly very central in organizational communication theory (Barge, Little, 2002). According to Grunig (2001), the variables in dialogical public relations are the intentions of the communication partners (symmetry and asymmetry), the direction of the communication process (one-way and two-way), the type 
of communication form used (mediated or interpersonal communication), and the extent to which public relations practice is ethical. Different studies proved that excellent public relations was both symmetrical and asymmetrical and both mediated and interpersonal, but always two-way and ethical, according to Grunig (2001, p. 30).

It cannot be denied that communication is important in Grunig's public relations model and that he holds the view that public relations is about communication with the aim to control and build mutual trust (200, p. 30). He laments only certain ways of communicating, not communication itself as a basic concept of public relations. Yet, it is still true, as Elizabeth L. Toth (1992, p. 9) already stated a long time ago, that Grunig did not enrich his theory by studying the concept of communication thoroughly. He does not define communication in his textbooks and overviews. Examining his texts, it is obvious that he and his fellow researchers focus on communication as exchange of information about interests of rational human beings - organizations and its stakeholder groups, for instance - in order to negotiate agreement (Ehling, 1992; Grunig, 1989). This approach to communication is based in the so-called balance models (Littlejohn, 1987, 1992, 2011), started by Theodore M. Newcomb (1953) and Fritz Heider (1958). The concern is with the degree of consistency which might exist between two persons in relation to a third person or object. Heider dealt with the internal cognitive processes to either of the two participants in a relationship, while Newcomb focused on the communication process between the two. Newcomb assumed that the communication process is the essential function of enabling two or more individuals to maintain simultaneous orientations to each other and towards objects in the environment.

Communication is thus a learned response under strain and we are likely to find "more" communication activity (seeking, giving and exchanging information) in conditions of uncertainty and turbulence (McQuail, Windahl, 1986, p. 21). The key aspect of this model is the relationship between $\mathrm{A}$ and $\mathrm{B}$, which is related to a communication process about $\mathrm{X}$ (something out there). Newcomb (1953) postulated a "strain to symmetry", resulting in a widening of the area of agreement by engaging in communication. That is to say, where there is balance, each participant will resist change, and where there is imbalance, attempts will be made to restore equilibrium.

The premise in all balance models is that people will always search for consistency (Stappers et al., 1990). Jack M. McLeod and Steven H. Chaffee (1973) modernized these models into the 
so-called co-orientation approach, combining balance models and certain aspects of symbolic interactionism, with emphasis on interpersonal communication and communication between groups, both two-way and interactive. Broom and Dozier (1986) used this co-orientation model as a basic model for public relations, but they changed the McLeod-and-Chaffee model insofar that their interest is not symbolic interactionism, but the accuracy/congruency of the interpretations of issues between stakeholders and organization. If there is no congruency, dialogue should help both parties to develop a congruent (i.e. denotative) interpretation. Grunig (2001) confirms this idea of co-orientation and congruency but does not explain this in terms of a communication model. My conclusion is that Grunig sees communication as consensus-building between (dependent) parties.

There are some more recent approaches to dialogue that are not so much oriented at consensusbuilding theory but at co-creation of new meanings as an ethical positive performance (see, for example, Kent, Taylor, 2002).

To sum up, in the reputation approach we find complete faith in the power of communication to reach certain predefined causal effects in cognitions and behaviors. Communication is no longer seen as a magic bullet, but a bullet it still is - and meaning problems are rather overlooked. This is best described as a transmission model of communication, which we defined as a non-communication approach. In the relationship and symmetry approaches we see not much interest in communication as a scientific concept but reading closely, it is obvious that the basis lies in balance models of communication.

The reputation, relationship and symmetry approaches have been rather dominant perspectives on public relations for quite some time now. It has become obvious that communication - although seen as an important tool for public relations - is not seen as a complex and dynamic process in which different actors play a role and meaning(s) are co-created. Yet, there are some alternative approaches in which communication is much more central and seen from a communication scientific point of view.

\subsection{The rhetorical approach}

A fourth approach to public relations is the rhetorical approach (Toth, Heath, 1992; Ihlen, 
2004; Heath, 2010). Although not very widespread, it is a well-respected approach, forming the basis of many of the chapters of Handbook of Public Relations (Heath, 2001a; 2010). In the rhetorical approach to public relations, communication plays a pivotal role. "Rhetoric can be thought of as a one-way flow of information, argument, and influence whereby one entity persuades and dominates another. (...) In the best sense, rhetoric should not be thought of as monologue, but dialogue. By featuring dialogue, we opt to emphasize the dynamics of rhetorical exchange by which interested parties seek to induce agreement and action." (Toth, Heath, 1992, p. xi-xii) Toth (1992, p. 3) is one of the few public relations scholars who suggests that communication is to be seen as the basis of public relations, since "public relations IS communicating” [capitals in the original, BvR], although communicating in a certain way.

In his 1994 book Management of Corporate Communication, Robert L. Heath (1994, p. 45) argued that for developing relationships, comparable zones of meaning are to be constructed, meant as comparable "social realities", in order to be able to coordinate efforts. In 2001 he follows the same line, arguing that "shared meaning" is a vital outcome of public relations and the constituting variable of relationships. Shared meaning is constructed through dialogue (Heath, 2001b, p. 31), which he sees as "statement and counterstatement that constitute the process and shape the content of rhetoric" (Heath, 2001b, p. 32).

We could say that, in the rhetorical approach, relationships are not built through communication but in communicating. This brings communication to the center of public relations, seen from a transactional model of communication. Communication is part of the rhetorical approach, focusing however, on interpersonal and organizational communication; the societal function of communication in shaping public opinion and the public sphere is largely overlooked.

\subsection{The community approach}

A fourth approach that can be found in the theoretical literature on public relations is the community-building approach developed by Dean Kruckeberg and Kenneth Starck (1988; see also Starck, Kruckeberg, 2000) and reported, for example, by K. A. Leeper and R. V. Leeper (2000). Kruckeberg and Starck (1988) defined public relations in a normative way, as the 
social conscience of an organization that is able to contribute to the mutual understanding among groups and institutions, and brings harmony to private and public policies. In such an approach, public relations is focused on "how to behave" in order to be a decent citizen. In the community approach, some forms of communication are seen as important as a means to build community. Kruckeberg and Starck (1988, p. 62; they also refer to Carey) claim that communication should be seen, not as "doing something to someone else", but as "doing something with someone". In their view, public relations should abandon "the transmission model of communication, that is, principles rooted in persuasion and advocacy rather than principles based on social involvement and participation”. So, Kruckeberg and Starck advocate a certain form of communication to be adopted in public relations theory. They even state that: "The public relations practitioner's role as a communicator, and more specifically as a communication facilitator, should be his or her highest calling” (Kruckeberg, Starck, 1988, p. 112). But they do not explain how this communication role is rooted in communication theory. At best, their communication theory will be one of consensus-building, but obviously that is most of all seen as a matter of good intentions.

\subsection{The societal approach}

In Scandinavian and German approaches, public relations is often treated from a societal perspective. Andrea Kückelhaus (1998) describes three approaches to public relations: product oriented, marketing oriented, and societally oriented. The product orientation could be equated with the one-way emission model (called "publicity model” by Grunig, Hunt, 1984), while the marketing orientation could be equated with Grunig's asymmetrical two-way model. However, the societal perspective cannot be equated with Grunig's two-way symmetrical model since the societal approach uses the society at large as unit of analysis and considers its social structure and institutions as the basis and the outcome of public relations. This implies that the main interest is not the corporation or organization itself, but its place in society at large (i.e., in the social structure). In this respect, society is seen from the perspective of what in German is called Öffentlichkeit ("in public"). Öffentlichkeit does not mean "public" as in publics, audiences, etc., but it means "public sphere", and more specifically, "what is potentially known to and can be debated by all" (Hollander, 1988). Öffentlichkeit is an outcome, and therefore a quality of the public communication system 
in society (Ronneberger, Rühl, 1992) and journalism, advertising, and public relations all play a role in developing or destroying the quality of this public communication system. Consequently, the public sphere cannot be seen as the aggregation of individual views (see Price, 1992, p. 2), but has a dynamic of its own and as such creates a symbolic reality. According to Kückelhaus, the societal orientation is the dominant approach in German public relations theory building. It is also dominant in Scandinavian public relations research. An essential aspect of public relations is its concern with issues and values that are publicly relevant and publicly debated, in other words, relating to the "public sphere", as the Danish scholar Inger Jensen (2000) argues. Øyvind Ihlen (2004), from Norway, combines the rhetorical approach with a societal approach and shows how public relations is an actor's play in a public battlefield of meanings, thereby contributing to "the" public meaning, e.g. to social reality. In this societal approach, public relations serves the same kind of (democratic) function as journalism does; both contribute to the free flow of information and its meanings, and to the development of the public sphere in size ("How many people are involved in public life?"), in level (“What is the level at which we discuss public matters?”), and in quality ("What are the frames used in the debates?"). This echoes what James W. Carey (1975) called a cultural approach to communication (communication produces cultural identity). In many European countries, theory building in public relations is closely related to journalism, not because the practitioners must deal with journalists, but because of these overlapping functions in society; the emphasis is on a transactional model of (public) communication. Obviously, communication plays a central role in this societal concept of public relations, concentrating on mass communication; the latter should not be equated with mass-mediated communications, but can best be understood as the "public communication system" than on producing society itself. In the European sociological approaches described above, legitimation is used to describe how an organization, as the exponent of one of the institutions in the social system, co-produces public policies and thereby the empirical realization of institutions, and, ultimately, society itself. An organization is legitimate as long as there is no public discourse concerning its legitimation. The societal approach is therefore a fundamental empirical approach and not a normative one, unlike the community approach. 


\section{Conclusion}

The literature on public relations shows that communication is mentioned in all approaches, implicitly or explicitly, and is typically seen as a facilitator. Moreover, in most approaches it is seen as a vital concept as long as it is used in a certain way. Given this centrality of communication, it is worrying that some authors propose to remove communication as a central concept and that many authors obviously do not consider it as a central concept that needs a scholarly, communication scientific approach. It is astonishing that it is obviously not considered important enough to study what the possibilities and constraints are.

Toth (1992, p. 3) argued that communication is underdefined in Grunig's approach to public relations. We must conclude that this is not only the case in Grunig's papers and books. According to Toth, communication is seen too much as the transfer of information, "as opposed to the more global rhetorical sense that, with communication, we transform our culture". The review of public relations literature shows that this is the case in all dominant approaches to public relations. Communication is very important but hardly explained in these public relations approaches and not seen as a difficult process of creation of meanings. Approaches that are oriented at communication as two-way meaning development or even as evolution - show a constructionist view of communication, can be found only in the less popular "schools" of public relations such as the rhetorical and societal approaches. John V. Pavlik's (1987) influential publication, Public Relations: What Research Tells Us, shows us why communication is seen as a marginal or even a removable concept in public relations. In the summary of his final chapter, Beyond Common Sense, Pavlik (1987, p. 119) writes:

"It may take more than communication to manage a relationship. Communication can accomplish only so much in today's society. It no longer has the power to influence public opinion the way it could in the days of P. T. Barnum or Ivy Lee. The role of communication today is more often limited to building mutual understanding (which is often of vital importance). Instead, relationship management may require corporate action of change."

According to Pavlik, producing understanding for decisions made by the organization is the only possible end of communication if getting others to think as you like them to think is no longer possible. In this view, communication is something that managers do to accomplish 
something else (cf. Conrad, Haynes, 2001, p. 53). It is striking that for Pavlik, organizational decision-making is obviously not a matter of communication. This is, again, an instrumental approach to communication but also a questionable one for public relations - not least because in theories of organizational communication, decision-making is seen as a communication process itself, in which meaningful decisions are constructed (Deetz, 2001) and in which, most of the time, organizational communication is seen as part of public relations/corporate communication. Decision-making is judging options and choosing one. Indeed, decision making is a communication process in which meanings are constructed and reconstructed, in which power is enacted and all kinds of communication roles are played. This varies from information and persuasion to dialogue and negotiation (Ruler, 2004).

That communication is not seen as a sufficient concept of public relations may be due to the assumption that public relations is just seen as communication with (or even towards) outsiders or employees about decisions made or to be made, and not the process in which decisions are being made. This is a narrow-minded view of communication in public relations. There is no evidence that communication in public relations should be limited to the communication processes with employees and stakeholders before or after decisions have been made. Moreover, it shows that in public relations the traditional sender-receiver model is still dominant; the manager is the sender and the employees or other stakeholders are the (more or less obstinate) receivers. It is beyond the "communication-as-mystery" model which many practitioners adhere to (Ruler, 1997), but it is still limited.

It might be helpful to conceptualize public relations as management of the processes of meaning creation (=communication) in order to build relationships/reputation/public trust/legitimation (see also Ruler, Verčič, 2005). In that case, public relations is fundamentally "management of communication processes in the context of organization" - i.e. communication management (as argued by Ruler, Verčič, 2005). If we see public relations as communication management, we create the space to study the process of meaning creation in the organizational and the organization-related societal context, first by challenging the question whose meaning is created by whom and what meaning means, then by finding out under what conditions what kinds of meanings are created. 


\section{Reference List}

- Argenti, P. A. (1994). Corporate communication. Burr Ridge, IL: Irwin.

- Barge, J. K., Little, M. (2002). Dialogical Wisdom, communicative Practice, and Organizational Life. Communication Theory. $12,375-397$.

- Bauer, R.A. (1964). The obstinate audience: the influence process from the point of view of social communication. The American Psychologist, 19, 319-328.

- Bentele, G., Rühl, M. (Eds.) (1993). Theorien öffentlicher Kommunikation [Theories of Public Communication]. München: Ölschläger.

- Berlo, D. K. (1960). The Process of Communication. New York: Holt, Rinehart and Winston.

- Bernays, E. L. (1923). Crystallizing Public Opinion. New York: Boni and Liveright.

- Bernays, E. L. (1955). The Engineering of Consent. Norman: University of Oklahoma Press.

- Birkigt, K., Stadler, M. M. (1986). Corporate Identity: Grundlagen, Funktionen, Fallspielen. Landsberg am Lech: Verlag Moderne Industrie.

- Broom, G. M., Casey, S., Ritchey, J. (2000). Concept and Theory of Organization-Public Relationships. In: Ledingham, J. A., Bruning, S. D. (Eds.) Public Relations as Relationship Management. A Relational Approach to the Study and Practice of Public Relations (pp. 3-22). Mahwah NJ: Lawrence Erlbaum.

- Broom, G. M., Dozier, D. M. (1986). Advancement for Public Relations Role Models. Public Relations Review, 7 (1), $37-56$.

- Broom, G. M., Sha, B. L. (2013). Effective Public Relations. Boston: Pearson.

- Carey, J. W. (1975). A Cultural Approach to Communication. Communication, 2 (1), 1-22.

- Conrad, C., Haynes, J. (2001). Development of key constructs. In: Jablin, F. M., Putnam, L. L. (Eds.), The New Handbook of Organizational Communication. Advances in Theory, Research, and Methods (pp. 47-77). Thousand Oaks: Sage.

- Cornelissen, J. (2014). Corporate Communication: A Guide to Theory and Practice. Thousand Oaks: Sage.

- Dance, F. E. X. (1970). A helical model of communication. In: Sereno, K. K., Mortensen, C. D. (Eds.). Foundations of Communication Theory (pp. 130-107). New York: Harper \& Row.

- Davis, A. (2002). Public Relations Democracy. Public Relations, Politics and the Mass Media in Britain. Manchester: Manchester University Press.

- Deetz, S. (2001). Conceptual Foundations. In: Jablin, F. M., Putnam, L. L. (Eds.), The New Handbook of Organizational Communication. Advances in Theory, Research, and Methods (pp. 3-46). Thousand Oaks: Sage.

- Dervin, B. (1991). Information as non-sense; Information as sense: the communication technology connection. In: Bouwman, H., Nelissen, P., Vooijs, M. (Eds.), Tussen vraag en aanbod [Between offer and supply] (pp. 44-59). Amsterdam: Cramwinckel.

- Dolphin, R. R. (1999). The Fundamentals of Corporate Communications. Oxford: Butterworth Heinemann.

- Ehling, W. P. (1992). Estimating the Value of Public Relations and Communication to an Organization. In: Grunig, J. E. (Ed.), Excellence in Public Relations and Communication Management (pp. 617-638). Hillsdale: Lawrence Erlbaum.

- Etang, J. L. (2004). Public Relations in Britain, a History of Professional Practice in the $20^{\text {th }}$ century. Mahwah: Erlbaum.

- Fauconnier, G. (1990). Mens en media [People and media]. Leuven, Belgium: Garant.

- Fombrun, Ch. J., Riel, C. B. M. van (2004). Fame \& Fortune. How successful Companies Build Winning Reputations. Upper Saddle River, NJ: Prentice Hall.

- Grunig, J. E. (1976). Organizations and Public Relations: Testing a communication theory. Journalism Monographs, 46.

- Grunig, J. E. (1989). Symmetrical Presuppositions as a Framework for Public Relations Theory. In: Botan, C. H., Hazleton Jr, V. (Eds.), Public Relations Theory (pp. 17-44). Hillsdale: Lawrence Erlbaum.

- Grunig, J. E. (1992). Communication, Public Relations, and Effective Organizations: An Overview of the Book. In: Grunig, J. E. (Ed.), Excellence in Public Relations and Communication Management (pp. 1-28). Hillsdale: Lawrence Erlbaum.

- Grunig, J. E. (2001). Two-Way Symmetrical Public Relations: Past, Present, and Future. In: Heath, R. L. (Ed.), Handbook of Public Relations (pp. 11-30). Thousand Oaks: Sage.

- Grunig, J. E., Hunt, T. (1984). Managing Public Relations. New York: Hilt, Rinehart and Winston.

- Grunig, L. A., Grunig, J. E., Dozier, D. M. (2002). Excellent Public Relations and Effective Organizations. A Study of Communication Management in Three Countries. Mahwah: Erlbaum. 
- Heath, R. L. (1994). Management of Corporate Communication. From Interpersonal Contacts to External Affairs. Hillsdale, NJ: Erlbaum.

- Heath, R. L. (Ed.) (2001a; 2010). Handbook of Public Relations. Thousand Oaks: Sage.

- Heath, R. L. (2001b). A Rhetorical Enactment Rationale for Public Relations: The Good Organization Communicating Well. In: Heath, R. L. (Ed.). Handbook of Public Relations (pp. 31-50). Thousand Oaks: Sage.

- Heath, R. L. (Ed.) (2013). Encyclopedia of Public Relations. Thousand Oaks: Sage.

- Heider, F. (1958). The Psychology of Interpersonal Relations. New York: John Wiley \& Sons.

- Hetebrij, M. (2011). Communicatief management. Tussen macht en communicatie [Communicative management. Between power and communication]. Alphen aan den Rijn: Samsom.

- Hollander, E. (1988). Lokale communicatie en locale openbaarheid. Openbaarheid als communicatiewetenschappelijk concept. [Local communication and local public sphere. Public sphere as communication scientific concept]. Nijmegen: Katholieke Universiteit Nijmegen.

- Ihlen, O. (2004). Rhetoric and Resources in Public Relations Strategies. A Rhetorical and Sociological Analysis of Two Conflicts over Energy and the Environment. Oslo: Unipub A. S (Ph.D. dissertation).

- Jensen, I. (2000). Public Relations and the Public Sphere in the Future. Paper presented at the $7^{\text {th }}$ International Public Relations Research Symposium, Bled, Slovenia, July, 7.

- Kent, M. L., Taylor, M. (2002). Toward a dialogic theory of public relations. Public Relations Review, 28 (1), 21-37.

- Kruckeberg, D., Starck, K. (1988). Public Relations and Community. A Reconstructed Theory. New York: Praeger.

- Kückelhaus, A. (1998). Public Relations: die Konstruktion von Wirklichkeit. Kommunikationstheoretische Annäherungen an ein neizeitliches Phänomen [Public Relations: Construction of Reality. Communication Scientific Perspectives for a recent phenomenon]. Opladen: Westdeutscher Verlag.

- Langer, S. (1967). Mind: An Essay on Human Feeling. Baltimore: John Hopkins University Press (cited in Littlejohn, S. W. (1992). Theories of Human Communication (pp. 67-70). Belmont, CA: Wadsworth.

- Ledingham, J. A., Bruning, S. D. (Eds.) (2000). Public Relations as Relationship Management. A Relational Approach to the Study and Practice of Public Relations. Mahwah NJ: Lawrence Erlbaum.

- Leeper, K. A., Leeper, R. V. (2000). Creating Community as Social Responsibility: A Case Study, paper presented at the International Communication Association, Acapulco, Mexico, June 1-5.

- Lin, N. (1971). Information flow, influence flow and the decision-making process, Journalism Quarterly, 48 (1),33-40.

- Littlejohn, S. W. (1983). Theories of Human Communication. Belmont, CA: Wadsworth.

- Littlejohn, S. W. (1992). Theories of Human Communication. Belmont, CA: Wadsworth.

- Litthejohn, S. W., Foss, K. A. (2011). Theories of Human Communication. Long Grove: Waveland Press.

- McLeod, J. M., Chaffee, S. H. (1973). Interpersonal approaches to communication research. American Behavioral Scientist, 16, 469-499.

- McQuail, D., Windahl, S. (1986). Communication Models. For the Study of Mass Communication. London: Longman.

- Newcomb, T. M. (1953). An Approach to the Study of Communicative Acts, Psychology Review, 60 (6), 393-404.

- Nillesen, A. B. (1998). Een queeste naar voorlichting. Communicatiewetenschap en de eerste stap op weg naar een theorie van voorlichting [A search for Enlightenment. Communication science and the first step towards a theory of "voorlichting"]. Nijmegen: KU Nijmegen.

- Pavlik, J. V. (1987). Public Relations. What Research Tells Us. Newbury Park: Sage.

- Preyer, G., Peter, G., Ulkan, M. (2003). Concepts of Meaning. Framing an Integrated Theory of Linguistic Behavior. Dordrecht/ Boston/London: Kluwer Academic Publishers.

- Price, V. (1992). Public Opinion. Newbury Park: Sage.

- Putnam, L. L., Pacanowsky, M. E. (Eds.) (1983). Communication and organizations. An interpretive approach. Beverly Hills: Sage.

- Riel, C. B. M. van (1995). Principles of Corporate Communication. London: Prentice Hall.

- Riel, C. B. M. van (Ed.) (2001). Corporate Communication. Het managen van reputatie [Management of reputation]. Alphen aan den Rijn: Kluwer.

- Riel, C. B. M. (2007). Defining Corporate Communication. In: Simcic Bronn, P., Wiig, R. (Eds.), Corporate Communication. A Strategic Approach to Building Reputation (pp. 277-294). Oslo: Gyldendal Akademisk. 
- Ronneberger, F., Rühl, M. (1992). Theorie der Public Relations, ein Entwurf (Theory of Public Relations, a design]. Opladen: Westdeutscher Verlag.

- Rosengren, K. E. (2000). Communication, an Introduction. London: Sage.

- Ruler, B. van (1997). Communication: Magical Mystery or Scientific Concept? Professional Views of Public Relations Practitioners in the Netherlands. In: Moss, D., MacManus, T., Verčič, D. (Eds.), Public Relations Research: An International Perspective (pp. 247-263). London: International Thomson Business Press.

- Ruler, B. van (2004). The communication grid: an introduction of a model of four communication strategies. Public Relations Review, 30, 123-143.

- Ruler, B. van, Verčič, D. (2005). Reflective Communication Management, Future Ways for Public Relations Research. In: Kalbfleisch, P. J. (Ed.), Communication Yearbook 29 (pp. 239-274). Mahwah: Erlbaum.

- Schramm (1965). How communication works. Schramm, W. (Ed.). The process and effects of mass communication (pp. 3-26). Urbana: University of Illinois Press.

- Schramm (1971). The nature of communication between humans. In: Schramm, W., Roberts, D. F. (Eds.), The process and effects of mass communication (pp. 3-53). Urbana: University of Illinois Press.

- Shannon, C. E., Weaver, W. (1949). The Mathematical Theory of Communication. Urbana: University of Illinois Press.

- Stappers, J. G., Reijnders, A. D., Möller, W. A. J. (1990). De werking van massamedia. Een overzicht van inzichten [How media work; an overview of insights]. Amsterdam, NL: Arbeiderspers.

- Starck, K., Kruckeberg, D. (2000). Public Relations and Community: A Reconstructed Theory Revisited. In: Heath, R., Vasquez, G. (Eds.), Handbook of Public Relations (pp. 51-59). Thousand Oaks: Sage.

- Susskind, L., McKearnan, S., Thomas-Larmer, J. (Eds.) (1999). The Consensus Building Handbook. A Comprehensive Guido to Reaching Agreement. Thousand Oaks: Sage.

- Thayer, L. (1968). Communication and communication systems in organization, management and interpersonal relations. Homewood Il: Richard D. Wirwin Inc.

- Thayer, L. (1987). On Communication, Essays in Understanding. Norwood NJ: Ablex.

- Toth, E. L. (1992). The Case for Pluralistic Studies of Public Relations: Rhetorical, Critical, and Systems Perspectives. In: Toth, E. L., Heath, R. L. (Eds.), Rhetorical and Critical Approaches to Public Relations (pp. 3-15). Hillsdale, NJ: Erlbaum.

- Toth, E. L., Heath, R. L. (Eds.) (1992). Rhetorical and Critical Approaches to Public Relations. Hillsdale, NJ: Erlbaum.

- Weick, K. E. (1995). Sensemaking in Organizations. Thousand Oaks: Sage.

- Wiener, N. (1948). Cybernetics or control and communication in the animal and the machine. New York: Wiley \& Sons. 


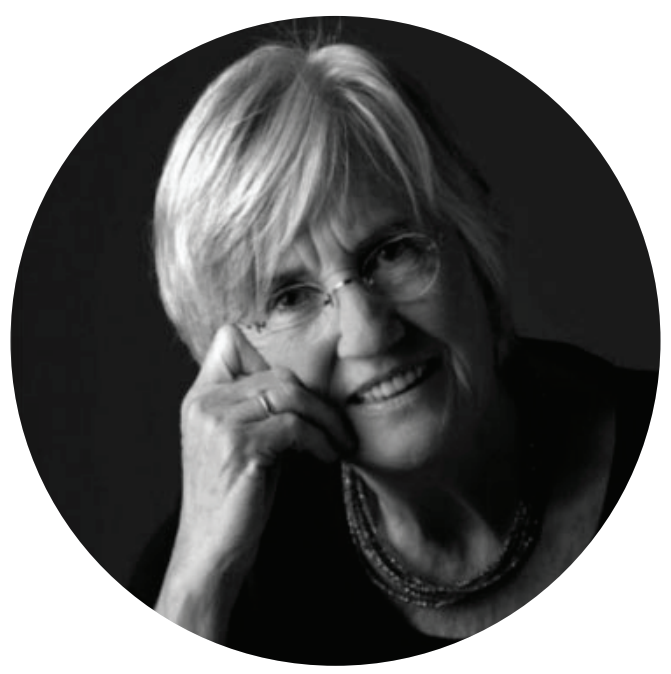

\section{Betteke van Ruler}

Betteke van Ruler (1948) is professor emerita in Communication Science, specialized in corporate communication and public relations at the University of Amsterdam. Prior to this, she was an associate professor in communication science and communication management at the Free University of Amsterdam. Her research is concerned with the practice of communication management and public relations, and the relationship between communication and organization. Van Ruler is past chair of the Public Relations Division of the International Communication Association (ICA), and past president of the European Public Relations Education and Research Association (EUPRERA). 